\title{
Studi Kestabilan Sistem dan Pelepasan Beban (Load Shedding) Berdasarkan Standar IEEE di PT. Pertamina (Persero) Refinery Unit IV
}

\author{
N. Nuswantara ${ }^{1}$ W.G. Ariastina ${ }^{2}$ A. A. N. Amrita $^{3}$ \\ Jurusan Teknik Elektro, Fakultas Teknik - Universitas Udayana \\ Email: nabilanuswantoro@ymail.com ${ }^{1}$ w.ariastina@unud.ac.id ${ }^{2}$ ngr amrita@ee.unud.ac.id ${ }^{3}$
}

\begin{abstract}
Abstrak
Dalam mengatasi kondisi overload generator saat terjadi gangguan yang menyebabkan ketidak stabilan, PT. Pertamina RU IV mengandalkan kerja load shedding berdasarkan SOP yang telah ditetapkan. Namun dalam pelaksanaannya prosedur SOP yang diberlakukan memiliki beberapa kekurangan, diantaranya adalah belum sesuai dengan standar IEEE yang berlaku global, waktu untuk menstabilkan kembali sistem cukup lama, serta seringkali terjadi pelepasan beban yang sebenarnya tidak perlu. Oleh karena itu, dilakukan studi terhadap kestabilan sistem dan load shedding yang diberlakukan dengan menggunakan standar IEEE sebagai acuan. Hasil studi menunjukkan, penggunaan load shedding IEEE untuk mengatasi masalah kestabilan sistem di PT. Pertamina RU IV lebih efektif, hal ini dapat dilihat dari hasil pengujian kestabilan sistem dimana prosedur load shedding IEEE berhasil menstabilkan kembali frekuensi sistem menjadi 99,85\% dalam waktu 23 detik, 98,5\% dalam waktu 8 detik, 99,16\% dalam waktu 40 detik menjadi $98,48 \%$ dalam waktu 70 detik pada 4 studi kasus yang dilakukan.
\end{abstract}

Kata Kunci : Load shedding, PT. Pertamina (Persero) RU IV, Stabilitas, Standar IEEE

\begin{abstract}
The study intends to explain the shortage of PT.Pertamina RU IV's SOP in order to overcome generator's instability during breakdown. The observation found that the problem occured due to PT. Pertamina RU IV policy to conduct the load shedding performance manually or with UFR (Under Frequency Relay) support to overcome breakdown. However this procedure came with some shortages. One of them was the standard procedure which has not met global IEEE standard yet and it took time to stabilize the system. Therefore to solve this problem, the IEEE standard imposed to be applied as a basic procedure. It showed the used of IEEE standard was more effective to overcome the system instability in PT. Pertamina RU IV because the study shows, the IEEE procedure could stabilized the system to $99,85 \%$ in 23 seconds, $98,5 \%$ in 8 seconds, $99,16 \%$ in 40 seconds and to $98,48 \%$ in 70 seconds on 4 different study cases.
\end{abstract}

Keywords: IEEE Standard, Load shedding, PT. Pertamina (Persero) RU IV, Stability

\section{PENDAHULUAN}

PT. Pertamina (Persero) Refinery Unit IV Cilacap merupakan kilang pengolahan minyak terbesar di Asia Tenggara. Untuk memberikan supply energi listrik kilang secara kontinyu PT. Pertamina Refinery Unit IV memiliki 8 unit pembangkit, dimana 4 unit pembangkit berkapasitas $8 \mathrm{MW}$ dan 4 unit berkapasitas 20 MW. Kedelapan pembangkit ini saling sinkron, sehingga apabila salah satu pembangkit trip maka beban dialihkan ke generator lainnya. Total beban yang harus disuplai adalah sebesar $78 \mathrm{MW}$ dan dipikul oleh kedelapan generator.

Walaupun sistem telah dirancang sehandal mungkin, pada proses pembangkit- an dapat terjadi gangguan yang tidak dapat dihindari, seperti terjadinya trip unit pembangkit yang mengakibatkan generator overload. Terjadinya overload pada generator akan mengakibatkan ketidakseimbangan antara daya mekanik yang dihasilkan oleh generator dengan daya elektrik yang dikonsumsi oleh beban sehingga mengakibatkan melambatnya putaran generator. Jika daya mekanik pada poros penggerak awal tidak dengan segera menyesuaikan dengan besarnya daya elektrik pada beban listrik, maka frekuensi dan tegangan akan bergeser dari nilai setting. Oleh karena itu, perubahan beban harus diikuti dengan perubahan daya penggerak generator. Hal 
ini dimaksudkan agar terjadi keseimbangan antara daya beban dan daya suplai [1].

Untuk mencapai keseimbangan daya, PT. Pertamina (Persero) RU IV memberlakukan skenario penanganan yang diawali dengan kerja governor system terlebih dahulu, apabila governor system gagal dalam mempertahankan kestabilan dan terdeteksi terjadi penurunan frekuensi sampai pada nilai frekuensi setting UFR, maka UFR akan otomatis membuka breaker beban sesuai urutan kepentingan beban tersebut, dan dibantu dengan load shedding secara manual oleh operator.

Skenario ini dinilai kurang efisien karena saat diberlakukan SOP load shedding seringkali terjadi pelepasan beban yang sebenarnya tidak perlu dan butuh waktu yang cukup lama bagi sistem untuk dapat kembali mencapai kestabilan. Selain itu belum pernah dilakukan studi untuk menguji kestabilan sistem dan kehandalan sistem load shedding sesuai dengan standar IEEE yang diberlakukan secara global sehingga belum diketahui apakah sistem kelistrikan yang dimiliki PT. Pertamina (Persero) Refinery Unit IV saat ini sudah cukup handal dan sesuai dengan standar.

Pada studi ini dilakukan simulasi gangguan yang dapat mengganggu kestabilan sistem, kemudian saat sistem tidak mampu stabil kembali, rancangan load shedding standar IEEE akan diberlakukan. Jumlah beban yang dilepas serta lama waktu yang dibutuhkan untuk menstabilkan kembali sistem menggunakan prosedur load shedding IEEE kemudian dibandingkan dengan kondisi eksisting yang diberlakukan saat ini, sehingga menghasilkan rekomendasi load shedding yang lebih efektif.

\section{Kestabilan Sistem Tenaga Listrik}

Kestabilan sistem tenaga listrik diartikan sebagai kemampuan dari sistem untuk menjaga kondisi operasi yang seimbang dan kemampuan sistem tersebut untuk kembali ke kondisi operasi normal ketika terjadi gangguan [2]. Sistem akan masuk pada kondisi ketidakstabilan ketika terjadi gangguan, peningkatan beban atau pada saat terjadi perubahan kondisi sistem yang disebabkan oleh drop tegangan yang tidak terkontrol sehingga nilai tegangan dan frekuensi bergeser dari nilai setting.

Suatu sistem tenaga listrik yang baik harus memenuhi beberapa syarat, seperti:

1. Reliability adalah kemampuan suatu sistem untuk menyalurkan daya atau energi secara terus menerus.

2. Quality adalah kemampuan sistem tenaga listrik untuk menghasilkan besaran-besaran standard yang ditetapkan untuk tegangan dan frekuensi.

3. Stability adalah kemampuan dari sistem untuk kembali bekerja secara normal setelah mengalami suatu gangguan [3].

Dalam sistem tenaga listrik yang baik maka ketiga syarat tersebut harus dipenuhi yaitu sistem harus mampu mem-beri pasokan listrik secara terus menerus dengan standar besaran tegangan dan frekuensi sesuai dengan aturan yang berlaku dan harus segera kembali normal bila sistem terkena gangguan.

\subsection{Skema Load shedding PT. Pertamina RU IV}

PT. Pertamina RU IV mengandalkan kerja load shedding untuk menyeimbangkan daya saat terjadi gangguan yang menyebabkan ketidak stabilan sistem, dimana load shedding ini merupakan perpanjangan dari Under frequency Relay (UFR). Relay frekuensi ini merupakan relay proteksi generator yang digunakan untuk mendeteksi adanya perubahan frekuensi sistem sampai kepada batas-batas tertentu.

Relay ini akan memerintahkan breaker untuk melepas beban apabila nilai frekuensi bergeser sampai dengan nilai trip yang ditentukan. Urutan trip frekuensi disesuaikan dengan prioritas beban kilang yang telah ditentukan oleh perusahaan. Prioritas utama yaitu beban-beban yang apabila dilepas tidak mengganggu produksi kilang serta tidak menimbulkan kerugian bagi perusahaan, sedangkan beban-beban yang perlu mendapat pelayanan listrik secara continue seperti kilang BBM tidak diprioritaskan untuk dilepas.

Pelepasan beban di PT. Pertamina RU IV terjadi dalam 3 tahap, tahap pertama pada frekuensi $49 \mathrm{~Hz}$, tahap kedua pada frekuensi $48,5 \mathrm{~Hz}$ dan tahap ketiga pada frekuensi $47,5 \mathrm{~Hz}$ [4]. Relay frekuensi sengaja disetting untuk melepas beban sebelum terjadi jatuh frekuensi yang signifikan untuk menjaga motor-motor produksi 
kilang dari kerusakan. Jumlah total beban yang dilepas pada setiap tahapan sesuai dengan masing-masing nilai frekuensi trip dapat dilihat pada Tabel 1.

Tabel 1 Skema Load shedding PT.Pertamina RU IV

\begin{tabular}{|c|l|l|}
\hline Tahap & \multicolumn{1}{|c|}{ Frekuensi (Hz) } & $\begin{array}{c}\text { Total Beban } \\
\text { Dilepas (MW) }\end{array}$ \\
\hline 1 & 49 & $6,68 \mathrm{MW}$ \\
\hline 2 & 48,5 & $23,81 \mathrm{MW}$ \\
\hline 3 & 47,5 & $6,72 \mathrm{MW}$ \\
\hline
\end{tabular}

\subsection{Skema Load shedding Standar IEEE}

IEEE Std C37 106-2003 merupakan standar yang digunakan untuk proteksi frekuensi abnormal dari pembangkit [5]. Standar ini digunakan untuk sistem dengan frekuensi $60 \mathrm{~Hz}$ [6]. Pada penelitian ini standar tersebut digunakan sebagai referensi untuk standar frekuensi sistem $50 \mathrm{~Hz}$. Adapun skema pelepasan beban dilakukan dengan skema 3 langkah seperti yang tertera pada Tabel 2 .

Tabel 2 Skema Load shedding 3 Langkah IEEE

\begin{tabular}{|c|c|c|c|}
\hline STEP & $\begin{array}{c}\text { Frequency } \\
\text { Trip Point } \\
\text { (Hertz) }\end{array}$ & $\begin{array}{c}\text { Percent of } \\
\text { Load } \\
\text { shedding } \\
(\%)\end{array}$ & $\begin{array}{c}\text { Fixed Time } \\
\text { Delay } \\
\text { (cycles) on } \\
\text { Relay }\end{array}$ \\
\hline 1 & 59.3 & 10 & 6 \\
\hline 3 & 58.9 & 15 & 6 \\
\hline & $\begin{array}{c}\text { As required } \\
\text { to arrest } \\
\text { decline } \\
\text { before 58.2 } \\
\mathrm{Hz}\end{array}$ & \multicolumn{1}{|}{} \\
\hline
\end{tabular}

\subsection{Sistem Kelistrikan di PT. Pertamina RU IV \\ PT. Pertamina (Persero) Refinery Unit} IV memiliki 3 plant pembangkit listrik. Pada masing-masing plant terpasang 3 unit generator berkapasitas $8 \mathrm{MW}$ di plant 50, 3 unit generator berkapasitas $20 \mathrm{MW}$ di plant 05 , 1 unit generator berkapasitas $20 \mathrm{MW}$ dan 1 unit generator $8 \mathrm{MW}$ di plant 500. Total daya yang dibangkitkan oleh sistem pembangkit padalah $112 \mathrm{MW}$.

Daya listrik kemudian disalurkan ke stasiun-stasiun beban yang terdiri atas beban statis dan beban motor [7]. Sebelum menuju stasiun beban daya dialirkan melalui machine bus generator, dimana setiap generator mempunyai satu unit machine bus.

Seluruh unit generator dioperasikan secara paralel. Kecuali terdapat generator yang dalam keadaan bermasalah atau sedang dalam perawatan, maka unit generator tersebut akan dikeluarkan dari sistem.

\section{METODELOGI PENELITIAN}

Proses pertama dalam penelitian adalah melakukan pengambilan data, setelah itu, proses selanjutnya adalah melakukan pemodelan sistem dengan menggunakan software Etap sehingga proses selanjutnya yakni analisis loadflow sistem dapat dilakukan. Setelah analisis loadflow, kemudian dilakukan simulasi gangguan dimana gangguan yang diterapkan adalah gangguan generator outage dan gangguan hubung singkat. Analisis terhadap respon perubahan frekuensi dan tegangan setelah gangguan kemudian dilakukan untuk mengetahui apakah sistem dapat kembali stabil atau tidak. Apabila kestabilan sistem jatuh, maka dilakukan prosedur pelepasan beban sesuai aturan SOP Pertamina dan IEEE skema 3 langkah untuk kemudian efektivitas kedua prosedur tersebut dibandingkan berdasarkan jumlah beban yang dilepas dan waktu yang dibutuhkan untuk menstabilkan kembali sistem.

\section{HASIL DAN PEMBAHASAN}

Simulasi gangguan dilakukan dengan menggunakan studi kasus pada Tabel 3 berikut

Tabel 3 Studi Kasus

\begin{tabular}{|l|l|}
\hline Kasus & Keterangan \\
\hline Kondisi 1 & $\begin{array}{l}\text { Sistem normal operation, } \\
\text { generator G301 trip. }\end{array}$ \\
\hline Kondisi 2 & $\begin{array}{l}\text { Sistem normal operation, } \\
\text { generator G103 trip. }\end{array}$ \\
\hline Kondisi 3 & $\begin{array}{l}\text { Sistem normal operation, } \\
\text { generator G1 dan G102 trip. }\end{array}$ \\
\hline Kondisi 4 & $\begin{array}{l}\text { Generator G1 dan G102 trip, } \\
\text { gangguan 3 phasa pada } \\
\text { machine bus }\end{array}$ \\
\hline
\end{tabular}

Sesuai Tabel 3, terdapat 3 bus yang digunakan sebagai indikator dalam analisis 
antara lain bus 50EES01 mewakili bus sistem yang berada pada plant 50 , bus 50EE2101 mewakili bus sistem yang berada pada plant 500 serta bus 05EE101C mewakili bus sistem yang berada pada plant 05. Studi kasus dilakukan berdasarkan hasil analisa loadflow dan kondisi real sistem kelistrikan kilang, seperti pada Gambar 1.

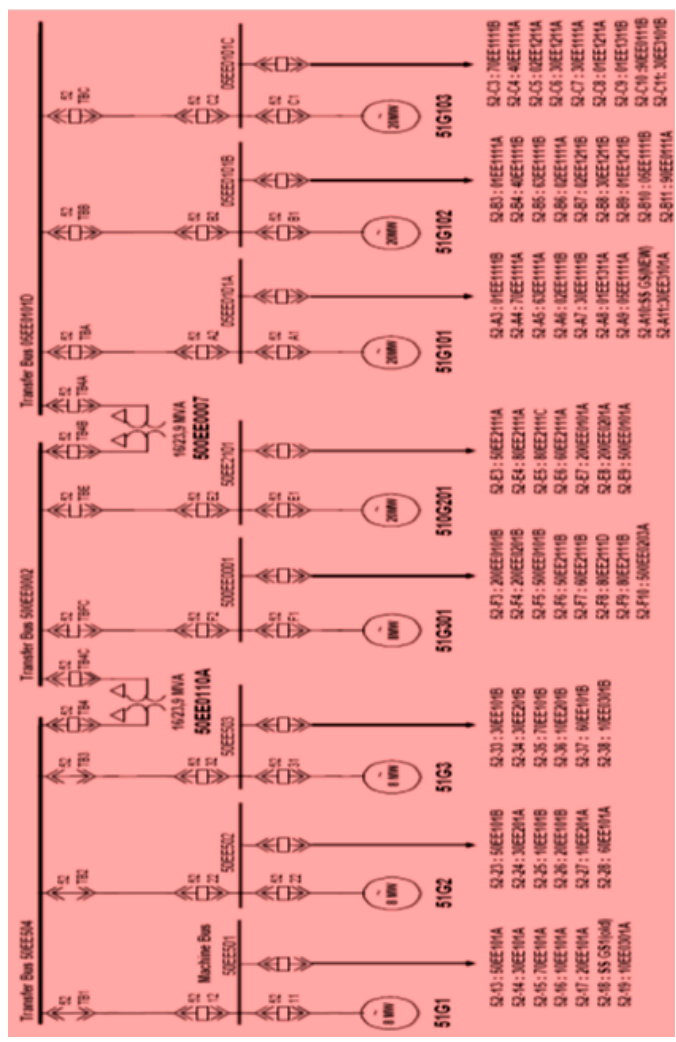

Gambar 1 Diagram PT. Pertamina RU IV

\subsection{Kondisi 1}

Pada kasus ini, sistem berada dalam kondisi normal operation dimana seluruh beban terpasang pada sistem dan seluruh generator dalam keadaan beroperasi, kemudian pada saat $\mathrm{t}=5$ detik generator G301 trip. Kondisi ini berlang-sung selama 120 detik.

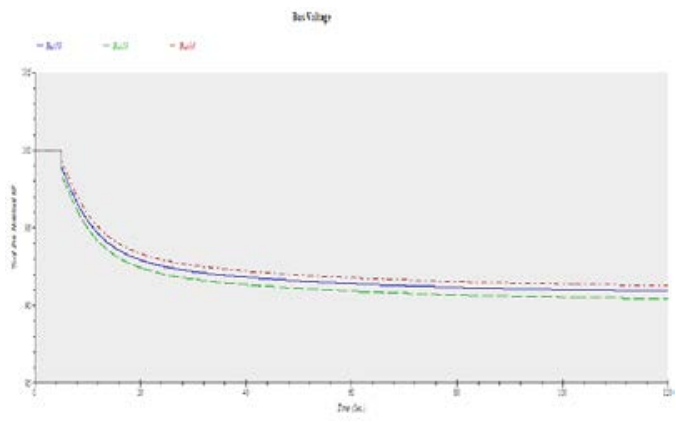

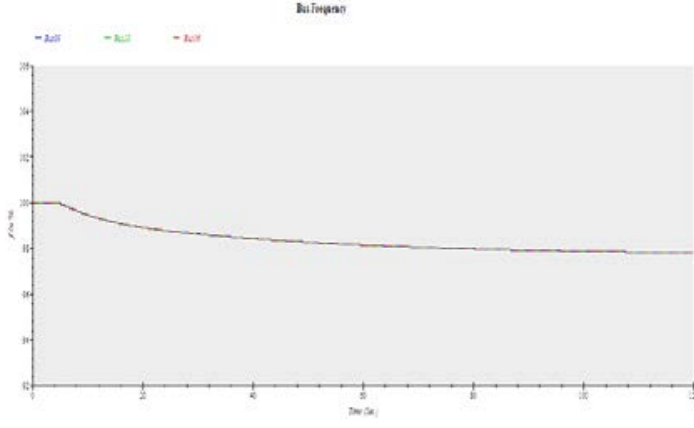

Gambar 2 Respon Tegangan dan Frekuensi Kondisi 1

Gambar 2 menunjukkan grafik respon tegangan (atas) dan respon frekuensi (bawah) pada kondisi 1, terlihat bahwa setelah generator $\mathrm{G} 301$ trip pada saat $\mathrm{t}=5$ detik, tegangan dan frekuensi pada masingmasing bus indikator mengalami penurunan. Tegangan turun menjadi $91 \%$ atau sekitar 12,548 kV pada akhir simulasi dan gagal untuk mempertahankan kestabilan. Sedangkan frekuensi turun menjadi 99,38 $\%$ atau $49,69 \mathrm{~Hz}$ dan terus menerus mengalami penurunan menjadi 97,82 \% atau $48,91 \mathrm{~Hz}$ pada akhir simulasi. Hal ini mengindikasikan bahwa sistem tidak stabil dan frekuensi sistem akan terus mengalami penurunan. Untuk itu dilakukan prosedur load shedding skema 3 langkah standar IEEE untuk mengembalikan sistem pada keadaan stabil.

Load shedding tahap 1 dilakukan pada saat $\mathrm{t}=22,6$ detik, dimana pada saat tersebut nilai penurunan frekuensi mencapai $98,83 \%$ atau $49,41 \mathrm{~Hz}$ sesuai aturan pelepasan beban standar IEEE. Adapun untuk load shedding tahap 1 beban yang dilepaskan sebesar 6,88 MW.

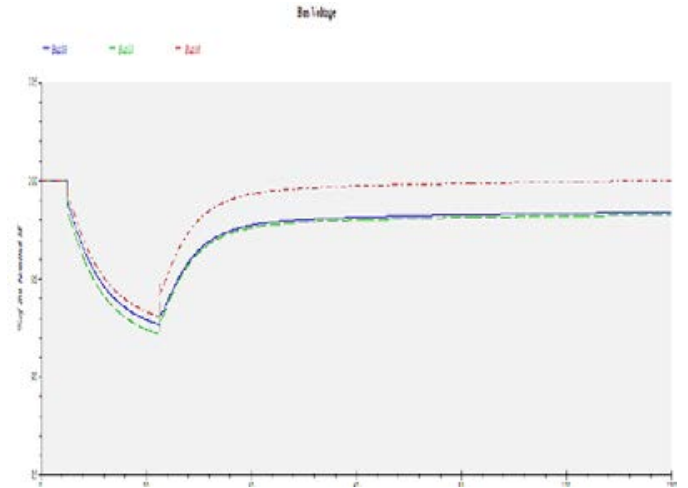




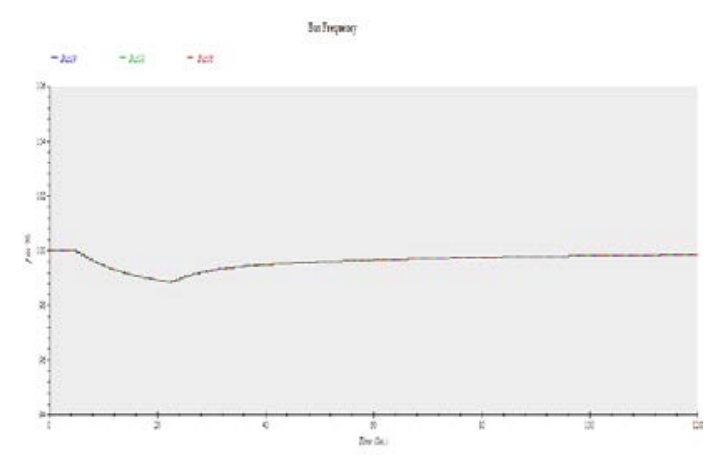

Gambar 3 Respon Tegangan dan Frekuensi Kondisi 1 Load shedding IEEE

Gambar 3 menunjukkan grafik respon tegangan (atas) dan respon frekuensi (bawah) pada kondisi 1 saat load shedding IEEE diberlakukan. Dapat dilihat bahwa saat beban mulai dilepas sesuai dengan aturan standar IEEE, tegangan dan frekuensi mulai mengalami kenaikan terus menerus hingga stabil kembali pada tegangan 13,578 kV dan frekuensi 99,85\% atau $49.91 \mathrm{~Hz}$ mulai dari detik ke 45 sampai dengan akhir simulasi, sehingga total waktu yang dibutuhkan untuk menstabilkan kembali sistem adalah 23 detik.

Sementara pada kondisi eksisting di PT. Pertamina RU IV, load shedding tahap 1 dilakukan pada saat $\mathrm{t}=65,6$ detik, dimana pada saat tersebut nilai penurunan frekuensi mencapai $98 \%$ atau $49 \mathrm{~Hz}$ dan beban yang dilepaskan sebesar 6,88 MW

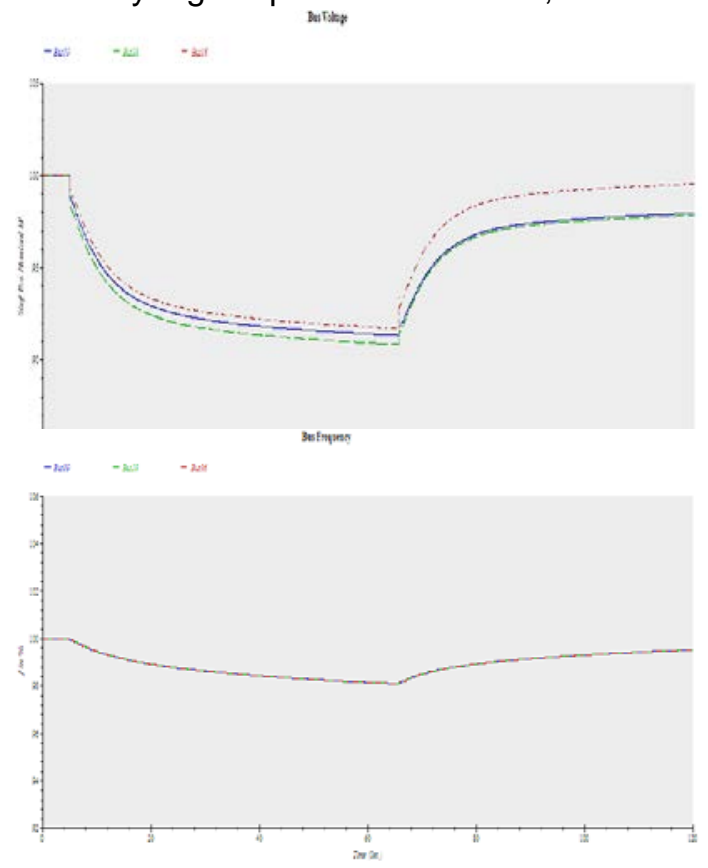

Gambar 4 Respon Tegangan dan Frekuensi Kondisi 1 Load Shedding Pertamina
Gambar 4 menunjukkan grafik respon tegangan (atas) dan respon frekuensi (bawah) pada kondisi 1 saat load shedding SOP Pertamina diberlakukan, dapat dilihat bahwa saat beban mulai dilepas tegangan dan frekuensi mulai menunjukkan kenaikan hingga mencapai titik 13,5 kV dan frekuensi 99,5\% atau pada 49,75 pada akhir simulasi, dengan total waktu yang dibutuhkan oleh sistem untuk mencapai titik stabil adalah 55 detik.

\subsection{Kondisi 2}

Pada kasus ini, sistem berada dalam kondisi normal operation dimana seluruh beban terpasang pada sistem dan seluruh generator dalam keadaan beroperasi, kemudian pada saat $\mathrm{t}=5$ detik generator G103 trip. Kondisi ini berlangsung selama 120 detik.
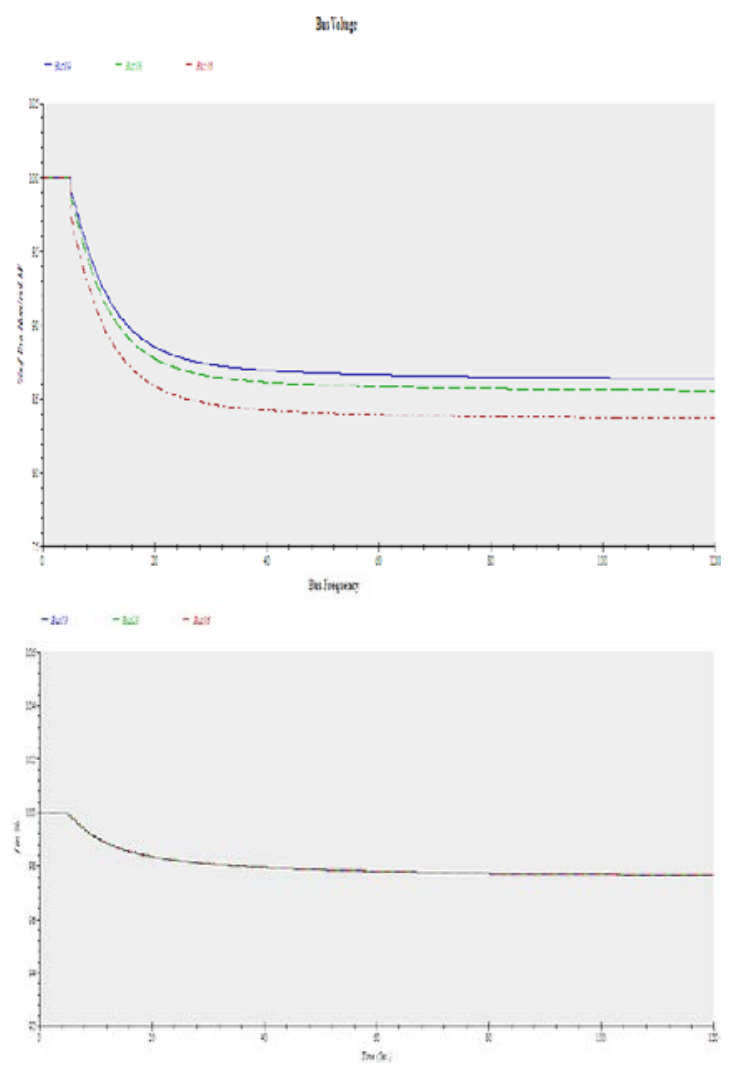

Gambar 5. Respon Tegangan dan Frekuensi Kondisi 2

Gambar 5 menunjukkan grafik respon tegangan (atas) dan respon frekuensi (bawah) pada kondisi 2. Dapat dillihat bahwa setelah generator G103 trip pada saat $\mathrm{t}=5$ detik, tegangan dan frekuensi mengalami penurunan. Tegangan turun menjadi $81 \%$ atau senilai $11,552 \mathrm{kV}$, sementara 
frekuensi turun menjadi $97,67 \%$ atau 48,83 $\mathrm{Hz}$. Untuk itu dilakukan prosedur load shedding skema 3 langkah standar IEEE untuk mengembalikan sistem pada keadaan stabil.

Load shedding tahap 1 dilakukan pada saat $\mathrm{t}=12$ detik, dimana pada saat tersebut nilai penurunan frekuensi mencapai $98,83 \%$ atau $49,41 \mathrm{~Hz}$ sesuai standar load shedding IEEE. Adapun untuk load shedding tahap 1 beban yang dilepaskan sebesar 6,88 MW.
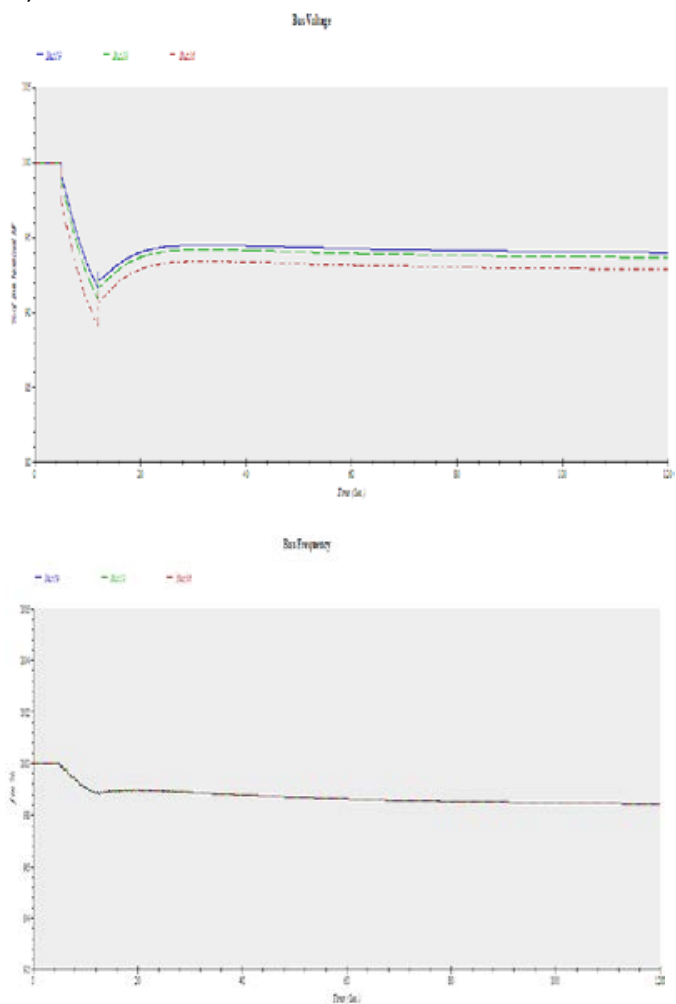

Gambar 6. Respon Tegangan dan Frekuensi Kondisi 2 Load shedding IEEE

Gambar 6 menunjukkan grafik respon tegangan (atas) dan respon frekuensi (bawah) pada kondisi 2 saat load shedding IEEE diberlakukan. Dapat dilihat saat beban mulai dilepas tegangan perlahanlahan mulai menunjukkan kenaikan hingga mencapai 12,819 kV sementara frekuensi mulai mengalami kenaikan sampai menjadi $98,45 \%$ atau $49,22 \mathrm{~Hz}$ pada saat $\mathrm{t}=20$. Sehingga total waktu yang dibutuhkan untuk menstabilkan kembali sistem adalah 8 detik.

Sementara pada kondisi eksisting di PT. Pertamina RU IV, load shedding tahap 1 dilakukan pada saat $\mathrm{t}=35,4$ detik saat nilai penurunan frekuensi mencapai $98 \%$ atau
$49 \mathrm{~Hz}$. Beban yang dilepaskan sebesar 6,88 MW.

Gambar 7 menunjukkan grafik respon tegangan (atas) dan respon frekuensi (bawah) pada kondisi 2 saat load shedding SOP Pertamina diberlakukan. Dapat dilihat bahwa saat beban dilepaskan, tegangan dan frekuensi mulai menunjukkan kenaikan hingga mencapai tegangan $12,83 \mathrm{kV}$ dan frekuensi $98,4 \%$ atau $49,2 \mathrm{~Hz}$. Total waktu yang dibutuhkan untuk menstabilkan kembali sistem adalah 20 detik.
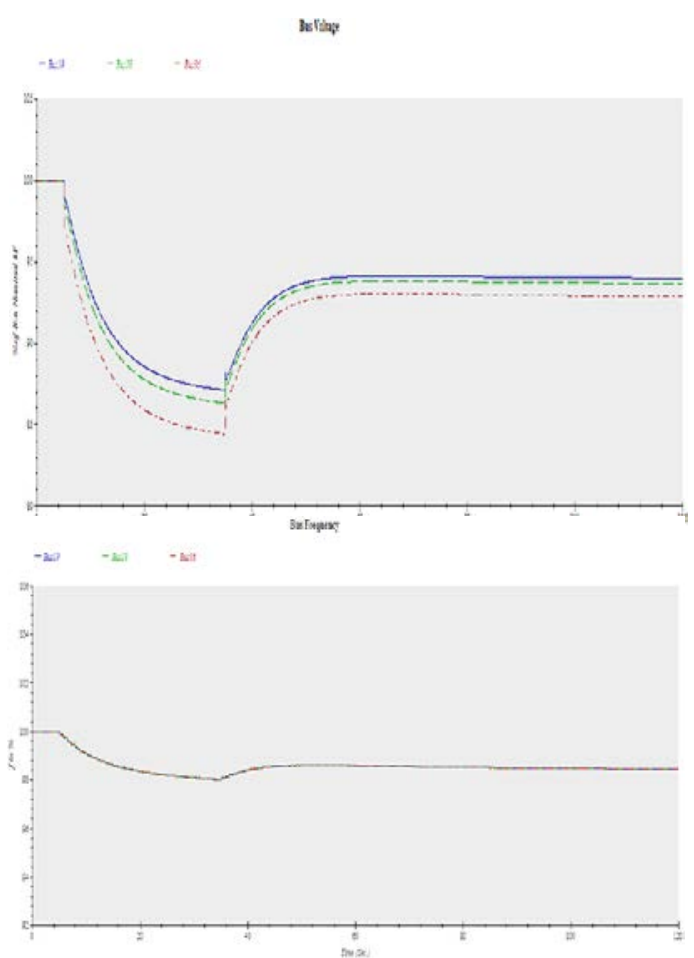

Gambar 7. Respon Frekuensi Kondisi 2 Load shedding Pertamina

\subsection{Kondisi 3}

Pada kasus ini, sistem berada dalam kondisi normal operation dimana seluruh beban terpasang pada sistem dan seluruh generator dalam keadaan beroperasi, kemudian pada saat $\mathrm{t}=5$ detik generator $\mathrm{G} 1$ dan G102 trip. Kondisi ini berlangsung selama 120 detik.

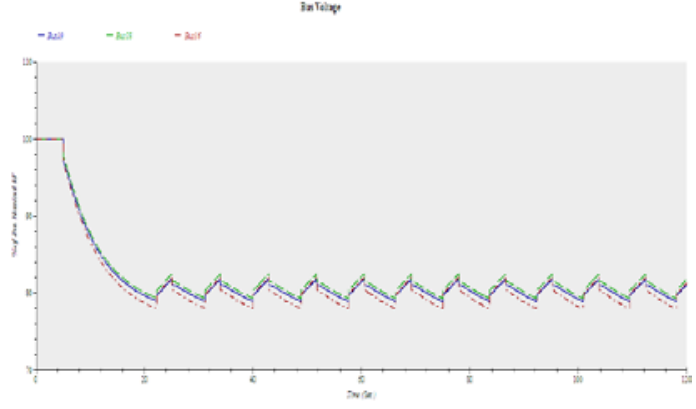




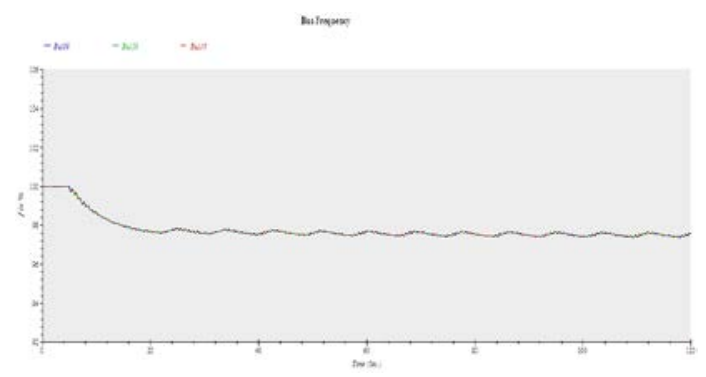

Gambar 8. Respon Tegangan dan Frekuensi Kondisi 3

Gambar 8 menunjukkan grafik respon tegangan (atas) dan respon frekuensi (bawah) pada kondisi 3. Dapat dilihat bahwa setelah generator G1 dan G102 trip tegangan dan frekuensi mengalami penurunan. Tegangan turun menjadi 10,93 kV kemudian mengalami naik-turun beberapa kali. Frekuensi turun menjadi 97,54 \% atau 48,7 Untuk itu dilakukan prosedur load shedding skema 3 langkah standar IEEE untuk mengembalikan sistem pada keadaan stabil.

Load shedding tahap 1 dilakukan pada saat $\mathrm{t}=8,72$ detik, dimana pada saat tersebut nilai penurunan frekuensi mencapai $98,83 \%$ atau $49,41 \mathrm{~Hz}$ sesuai aturan load shedding IEEE. Adapun untuk load shedding tahap 1 beban yang dilepaskan sebesar 6,88 MW.
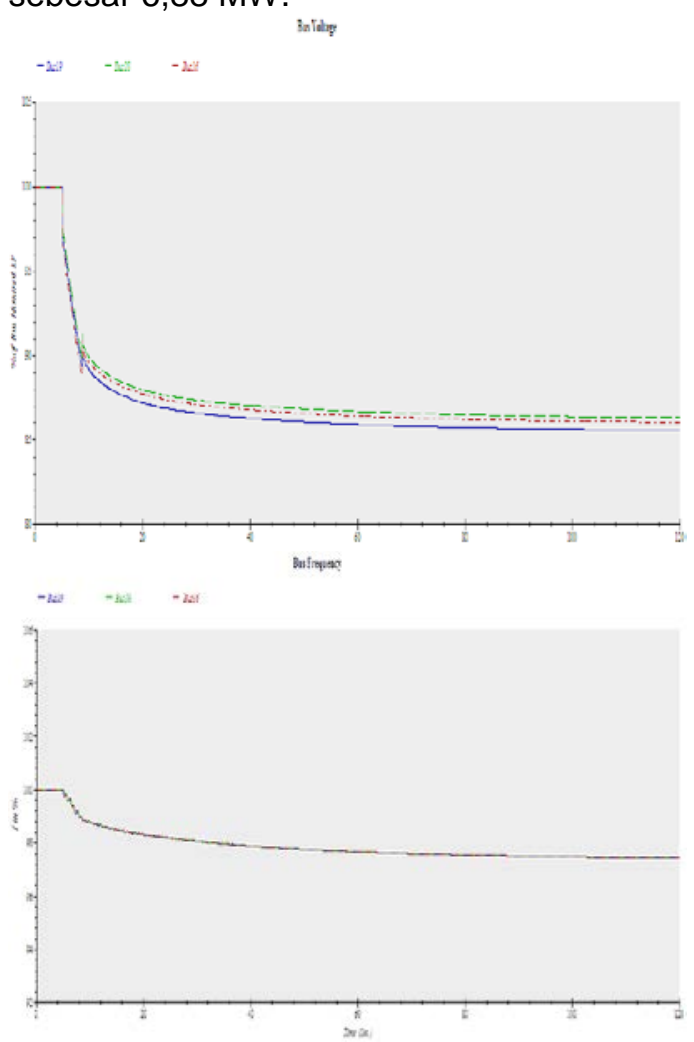

Gambar 9. Respon Tegangan dan Frekuensi Load shedding IEEE Kondisi 3
Gambar 9 menunjukkan grafik respon tegangan (atas) dan respon frekuensi (bawah) pada kondisi 3 saat load shedding IEEE diberlakukan, Dapat dilihat bahwa terjadi kenaikan tegangan menjadi $12,35 \mathrm{kV}$ dari sebelumnya $12,326 \mathrm{kV}$ pada bus 50EES01. Kemudian tegangan terus turun hingga menjadi $11,87 \mathrm{kV}$. Sementara frekuensi mulai mengalami sedikit kenaikan namun perlahan-lahan turun kembali menjadi $97,5 \%$.

Dari respon tersebut dapat dilihat bahwa sistem masih dalam kondisi belum stabil dan masih memerlukan bantuan load shedding untuk kembali ke titik stabil, untuk itu maka perlu dilakukan load shedding tahap kedua untuk mengembalikan kestabilan sistem.

Load shedding tahap 2 dilakukan pada saat $\mathrm{t}=28,08$ detik, dimana pada saat tersebut nilai penurunan frekuensi mencapai $98,1 \%$ atau $49,05 \mathrm{~Hz}$ sesuai aturan load shedding IEEE tahap 2, beban yang dilepaskan sebesar 7,401 MW.
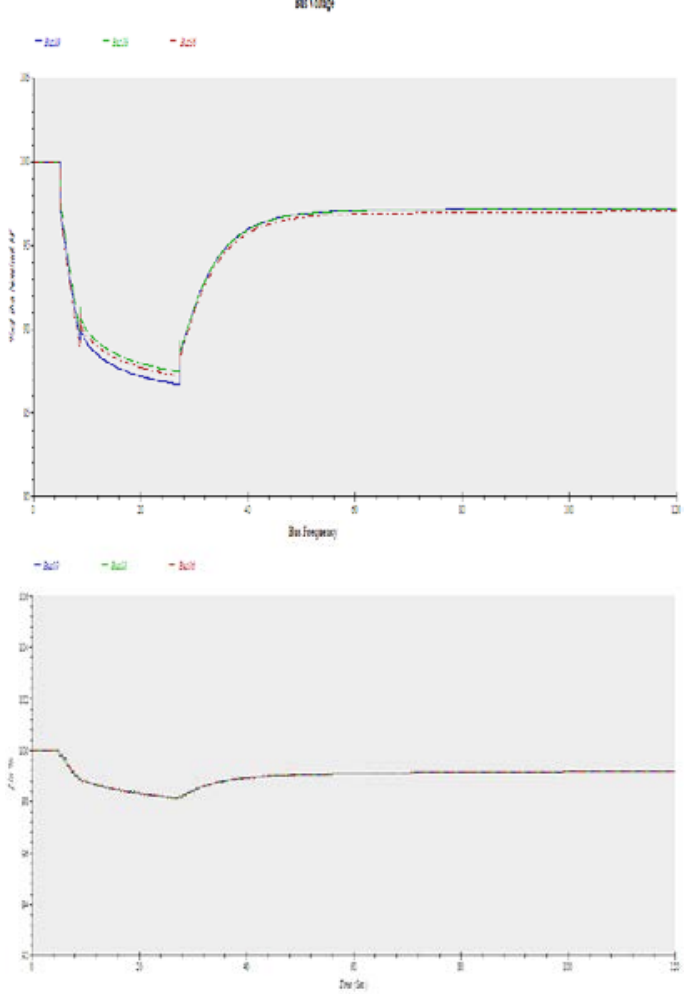

Gambar 10. Respon Tegangan dan Frekuensi Load shedding IEEE tahap 2 Kondisi 3

Gambar 10 menunjukkan grafik respon tegangan (atas) dan respon frekuensi (bawah) pada kondisi 3 saat load shedding IEEE tahap 2 diberlakukan. Dapat dilihat bahwa setelah beban dilepas tegangan 
mulai mengalami kenaikan hingga akhirnya stabil pada $\mathrm{t}=68$ detik di $13,4 \mathrm{kV}$ sementara frekuensi sistem mengalami kenaikan hingga akhirnya stabil pada $\mathrm{t}=68$ detik di $99,1 \%$ dan naik menjadi $99,16 \%$. Sehingga total waktu yang dibutuhkan untuk menstabilkan kembali sistem adalah 40 detik.

Sementara pada kondisi eksisting di PT. Pertamina load shedding dilakukan pada saat $\mathrm{t}=14,64$ detik, dimana pada saat tersebut nilai penurunan frekuensi mencapai $98 \%$ atau $49 \mathrm{~Hz}$. Adapun beban yang dilepaskan pada prosedur ini sebesar 6,88 MW.
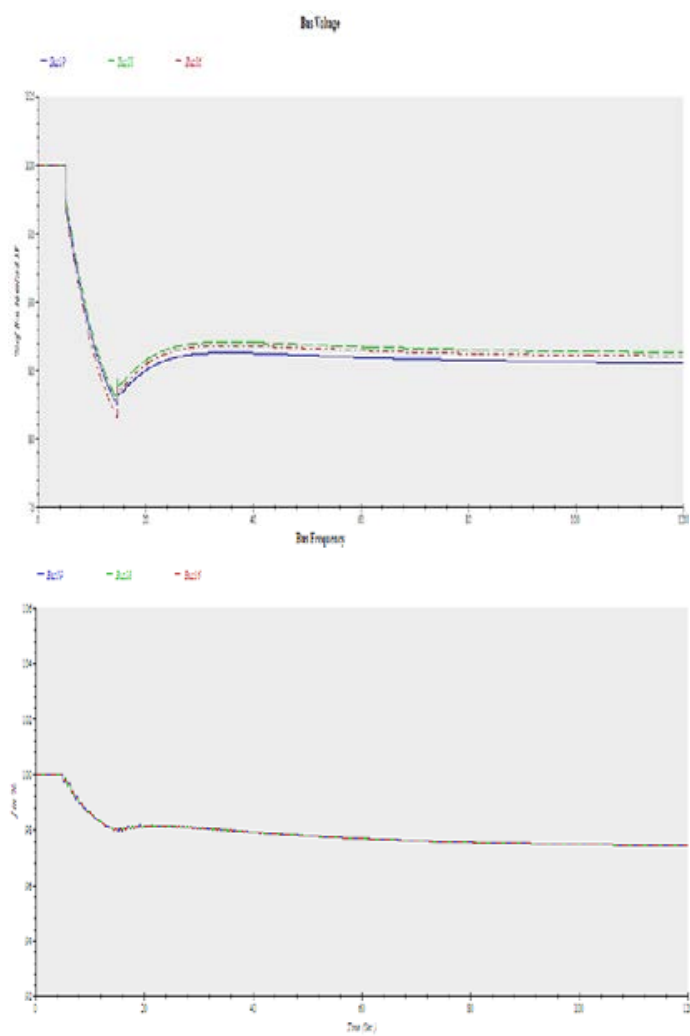

Gambar 11. Respon Tegangan dan Frekuensi Load shedding Pertamina Kondisi 3

Gambar 11 menunjukkan grafik respon tegangan (atas) dan respon frekuensi (bawah) pada kondisi 3 saat load shedding SOP Pertamina diberlakukan. Dapat dilihat bahwa setelah beban dilepas terjadi kenaikan tegangan dan frekuensi. Kemudian setelah $\mathrm{t}=40$ detik tegangan dan frekuensi terus mengalami penurunan yang cukup signifikan dan tidak berhasil menstabilkan kembali sistem.

\subsection{Kondisi 4}

Pada kasus ini, sistem berada dalam kondisi normal operation dimana seluruh beban terpasang pada sistem dan seluruh generator dalam keadaan beroperasi, kemudian pada saat $\mathrm{t}=5$ detik terjadi trip pada generator $\mathrm{G} 1$ dan $\mathrm{G} 102$ lalu pada $\mathrm{t}=$ 5,8 detik terjadi gangguan 3 phase pada bus 50EE101. Kondisi ini berlangsung selama 120 detik.

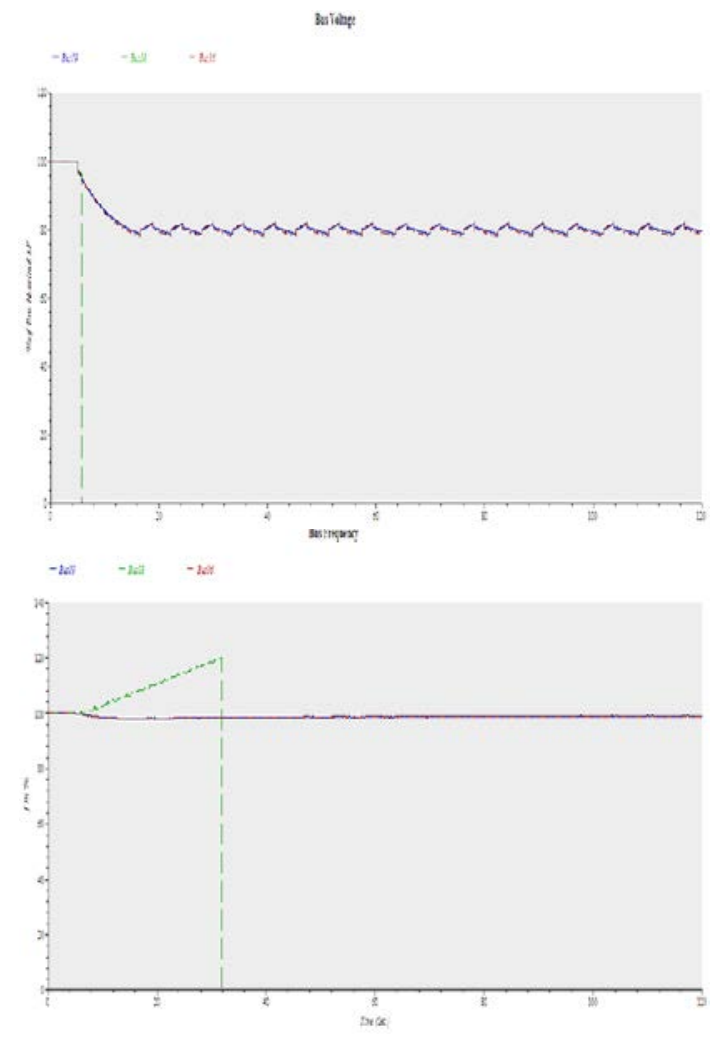

Gambar 12. Respon Tegangan dan Frekuensi Kondisi 4

Gambar 12 menunjukkan grafik respon tegangan (atas) dan respon frekuensi (bawah) pada kondisi 4. Dapat dilihat bahwa tegangan dan frekuensi tetap konstan berada pada angka $13,8 \mathrm{kV}$ sebelum terjadi generator trip dan gangguan 3 phasa. Tegangan dan frekuensi terus mengalami penurunan hingga akhirnya naik-turun hingga akhir simulasi sehingga perlu dilakukan metode load shedding untuk menstabilkan kembali sistem.

. Load shedding IEEE dilakukan saat $\mathrm{t}=8,62$ detik dimana pada saat tersebut nilai penurunan frekuensi mencapai 98,83\% atau $49,41 \mathrm{~Hz}$ sesuai aturan load shedding IEEE, beban yang dilepas adalah sebesar 6.68 MW sesuai dengan standar IEEE 
Gambar 13 berikut menunjukkan grafik respon tegangan (atas) dan respon frekuensi (bawah) pada kondisi 4 saat load shedding IEEE diberlakukan.

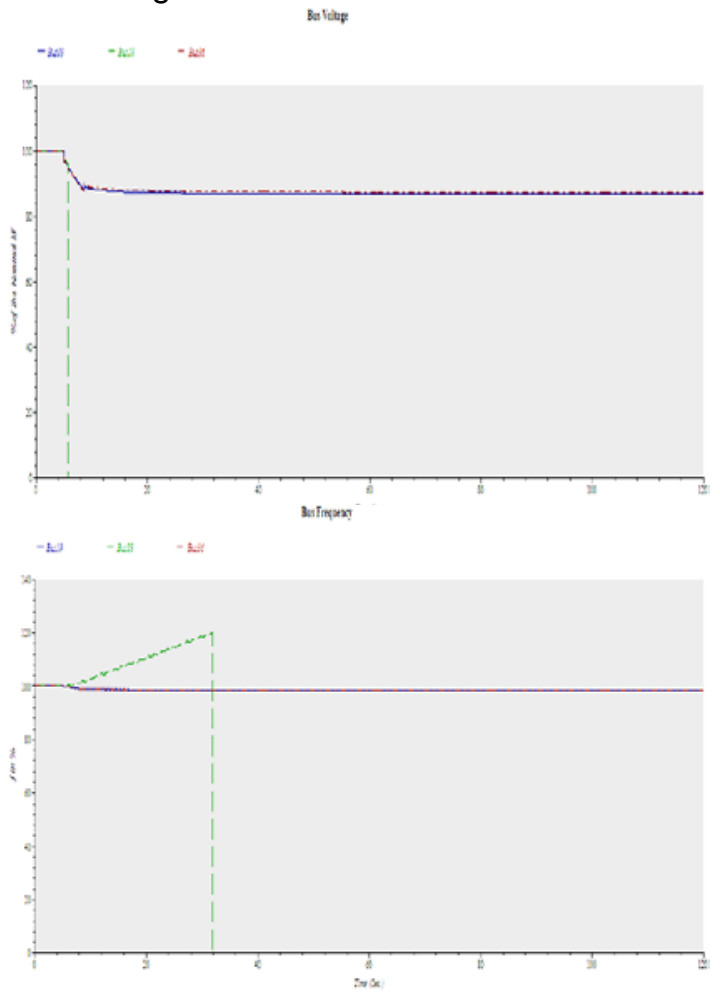

Gambar 13. Respon Frekuensi Load shedding IEEE Kondisi 4

Dapat dilihat bahwa setelah dilakukan load shedding tegangan dan frekuensi perlahan- lahan mengalami kenaikan dan menjadi stabil pada tegangan $12,09 \mathrm{kV}$ dan frekuensi $98,48 \%$ atau $49,24 \mathrm{~Hz}$ di detik $\mathrm{t}=80$. Total waktu yang dibutuhkan unttuk menstabilkan kembali sistem adalah 71 detik.

Pada kondisi eksisting sistem load shedding belum bekerja. Hal tersebut dikarenakan nilai penurunan belum sampai kepada nilai frekuensi trip, sehingga sistem masih dalam kondisi belum stabil dimana penurunan tegangan dan frekuensi masih terjadi.

\section{SIMPULAN}

Berdasarkan pengujian kestabilan sistem dan load shedding dengan melakukan simulasi beberapa kondisi gangguan terhadap system, maka dapat diambil kesimpulan bahwa penggunaan load shedding IEEE Std C37 106-2003 skema 3 langkah untuk mengatasi masalah kestabilan sistem di PT. Pertamina RU IV terbukti lebih efektif, hal ini dapat dilihat dari pengujian kestabilan sistem dengan hasil sebagai berikut :

a. Pada kondisi 1 dimana dilakukan pengujian kestabilan sistem dengan menerapkan gangguan trip pada generator G301, prosedur load shedding IEEE berhasil menstabilkan kembali frekuensi sistem menjadi $99,85 \%$ dalam waktu 23 detik dengan melepaskan beban sebesar 6,88 MW.

b. Pada kondisi 2 dimana dilakukan pengujian kestabilan sistem dengan menerapkan gangguan trip pada generator G103, prosedur load shedding IEEE berhasil menstabilkan kembali frekuensi sistem menjadi $98,5 \%$ dalam waktu 8 detik dengan melepaskan beban sebesar 6,88 MW.

c. Pada kondisi 3 dimana dilakukan pengujian kestabilan sistem dengan menerapkan gangguan trip pada generator $\mathrm{G} 1$ dan $\mathrm{G} 102$, prosedur load shedding IEEE berhasil menstabilkan kembali frekuensi sistem menjadi 99,16\% dalam waktu 40 detik dengan melepaskan beban sebesar 8,78 MW

d. Pada kondisi 4 dimana dilakukan pengujian kestabilan sistem dengan menerapkan gangguan trip pada generator G1 dan G102, prosedur load shedding IEEE berhasil menstabilkan kembali frekuensi sistem menjadi $98,48 \%$ dalam waktu 70 detik dengan melepaskan beban sebesar 6,88 MW

\section{DAFTAR PUSTAKA}

[1] Saadat H. Power System Analysis. USA : The Mc-Grew Hills.Inc.1999: 189-204

[2] Putera DF, Penansang O, Soeprijanto A. Analisis Kontingensi Sistem Kelistikan Sulawesi Selatan dan Barat on Proc. Seminar Tugas Akhir Jurusan Teknik Elektro FTI-ITS. Surabaya. 2010: 12-17

[3] Kundur PS. Power System Stability and Control Course. USA The McGrew Hills.Inc. 1994: 105-106

[4] Nugroho A. Analisa Transient Stability dan Pelepasan Beban Pengembangan Sistem Integrasi $33 \mathrm{kV}$ di $P T$. 
Pertamina RU IV Cilacap on Proc. Seminar Tugas Akhir Jurusan Teknik Elektro FTI-ITS. Surabaya. 2010: 1-6

[5] IEEE Standards Association. C37 1062003. Definition and Classification of Power System. New York: IEEE Press; 2004.

[6] Hidayat S. Analisis Kestabilan Transien dan Mekanisme Pelepasan Beban di PT. Pertamina (Persero) Refinery Unit (R.U.) VI Balongan Jawa Barat. Jurnal Teknik POMITS. 2013; 1(1): 1-6

[7] Amri U. Studi Stabilitas Transien di PT. Pertamina UP IV Cilacap Akibat Penambahan Pabrik Baru on Proc. Seminar Tugas Akhir Jurusan Teknik Elektro FTI-ITS. Surabaya. 2011: 1-6 